\title{
Mapping Dynamic Indicators of Quality of Life: a Case in Rosario, Argentina
}

\author{
Javier Martinez ${ }^{1}$
}

Published online: 17 April 2018

(C) The Author(s) 2018

\begin{abstract}
Mapping temporal changes of quality of life conditions reflecting the wellbeing of individuals, communities and urban areas has the potential to identify spatial patterns and trends towards prosperous and just societies. This paper presents an approach to map and to compare quality of life variations in time and space across districts and neighbourhood areas of the city of Rosario (Argentina). Census data (1991, 2001 and 2010) have been used to map and trace the trajectories of neighbourhood areas in relation to objective quality of life conditions. As a result, trends in improving the quality of life and reducing inequalities between neighbourhood areas are visualized. Three main outcomes have been found: divergence, convergence and maintenance of the status quo. The paper concludes reflecting on the emerging patterns and critically exploring how these mappings and representations can be used to better inform policy makers and potentially improve community well-being.
\end{abstract}

Keywords Intra-urban quality of life - Dynamic indicators - Spatial and temporal patterns - Rosario (Argentina)

\section{Introduction}

Mapping temporal changes of quality of life conditions reflecting the well-being of individuals, communities and urban areas has the potential to identify spatial patterns and trends towards prosperous and just societies. This potential is very much related to discussions of equity (Hay 1995) and the geography of social justice in particular (Smith 1994).

Javier Martinez

j.martinez@utwente.nl

1 ITC, University of Twente, Enschede, The Netherlands 
However, further research is needed on (1) how to better analyse and visualize the spatio-temporal quality of life change and (2) how to critically explore the capacities and potential of dynamic indicators of spatial inequality to better inform policy makers.

This paper looks into these two questions by adapting and testing a framework that facilitates the geo-visualization of patterns of change. It relies on empirical research comparing variations in time and space across districts and neighbourhood areas of the city of Rosario (Argentina). Census data and a Geographic Information System (GIS) have been used to map and trace the trajectories of neighbourhood areas in relation to objective quality of life conditions. In this methodology, temporal comparisons between the years 1991 and 2001 and 2001 and 2010 are performed to monitor the trends in improving the quality of life and reducing inequalities between neighbourhood areas. Three main outcomes are found:

- Divergence: an increase in the inequalities (gaps are growing);

- Convergence: a decrease in the inequalities (gaps are being reduced);

- Maintenance of the status quo: no change (gaps remain).

This paper first introduces the concept of dynamic socio-territorial indicators and how they have been used in studies of patterns of inequality and the importance of studying spatial patterns in quality of life studies (the second section); it then discusses the proposed methodology to map the spatio-temporal change of quality of life conditions (the third section); it critically presents and discusses the results (the fourth section) before concluding on the limitations and potentials of the approach.

\section{Dynamic Indicators}

\section{Socio-Territorial Indicators: Studies of Patterns of Inequality}

Several authors have theorized on the importance of geography and space in issues affecting (social) justice (Harvey 1973, 1997, 2000; Smith 1994; Soja 2010). Soja (2010, p. 19) - while arguing on the increasing importance of spatial thinking - indicates that "the geographies in which we live can have both positive and negative effects on our lives. They are not just dead background or a neutral physical stage". Socioterritorial indicators have the potential to make evident these geographies of social justice and patterns of inequality.

Among the first studies of socio-territorial indicators and mapping of quality of life conditions were those of Booth (1902) in London where primary data collection and households surveys had an important role. With the consolidation of national census practices, both deductive and inductive or exploratory approaches were developed to map multiple variables and describe social characteristics of urban areas. In the 1920s, the Chicago ecologist school developed the concept of natural areas characterised both by "physical individuality and by the cultural characteristics of the people who live in it" (Zorbaugh 1961, in Pacione 2001, p. 348). One of the critiques of natural areas is that they depend on a limited set of variables and that they have no theoretical base to justify the use of the selected variables. In contrast, deductive approaches such as the work on social area analysis of Shevky and Bell (1955, in Pacione 2001, p. 350) used a 
multivariate classification method derived from a theory on social change based on three main expressions or constructs (i.e. social rank or economic status, urbanisation or family status and segregation or ethnic status).

Many studies of patterns of inequality and spatial differentiation relied on the use of indicators of personal income (e.g. Chakravorty 1996; Smith 1973, 1994). However, as Knox and Pinch (2000, p. 100) put it: "while socioeconomic differentiation is arguably the most important cleavage within contemporary cities, it is by no means the only one". Other axis of differentiation exist (e.g. gender, ethnicity) and certainly other dimensions rather that income explain spatial inequality patterns. Markedly, this recognition of multidimensionality is shared by most of quality of life studies.

Another inductive approach used to reflect multidimensionality is that of factor analysis and multivariate statistical techniques. This approach has become one of the most widely used methods for measuring urban socio-spatial differentiation (Knox and Pinch 2000). The relationships and spatial patterns, which the factors describe - known as factorial ecology - are the product of exploratory analysis of a larger data set (Pacione 2001). Each of the resulting factors can be thought of as a macro or "super variable" that represents a cluster of highly correlated census-based variables. The meaning of each factor can be allied with the original variables that it is most strongly associated with.

Some of the limitations of factor analysis and similar approaches that make use of census data to study spatial patterns are that of ecological fallacy problems and MAUP (modifiable areal unit problems) ${ }^{1}$. The implicit assumption in the methodology is that these territories are homogeneous (ecological fallacy issue). Knox and Pinch (2000, p. 123) explain one of the problems of ecological fallacy (i.e. making inferences about individuals using data based on aggregates of people): "Thus not everyone in a deprived area is necessarily deprived and not every deprived person in an area of 'multiple deprivation' is necessarily multiply deprived". MAUP problems occur when size and configuration of spatial units may affect the outcome of the analysis: what is significant at one scale may not be significant at another (Rogerson 2010). Knox and Pinch (2000) consider that the territorial units for which aggregate census data are published may also have a considerable effect upon the analysis, since census sub-areas will not match actual patterns of residential variation on the ground. Besides, census sub-areas represent only one of the very large number of ways that a city can be subdivided, thus raising the question as to whether the same factorial ecology would result from different spatial frameworks.

Some studies of patterns of inequality encourage the use of indices. Smith (1973, pp. 120-134) carried out a study on the geography of social well-being in the city of Tampa using 47 "intra-city indicators" grouped into six criteria indicators (based on economic status, environment, health, education, social disorganisation, and participation and equality) and a general index to measure the general social well-being. Some of the problems of the use of indices are related to the difficulty for policy makers to interpret their results directly. Some authors consider that an aggregated index has virtually no diagnostic value: "To say that certain areas get high scores is not to give an idea what to do" (Innes 1990, p. 223). She also agrees on the idea of keeping dimensions separate

\footnotetext{
${ }^{1}$ Another criticism of traditional factorial analysis was reflected in the $1990 \mathrm{~s}$ in a renewed interest in social indicators, mainly because of growing social inequality in Western societies and a focus on ideas of social exclusion that defines poverty also in dimensions such as social participation (Knox and Pinch 2000).
} 
and letting decision makers apply their own value judgements and models. Regarding the difficulties of explaining them to users, Innes gives the example that they would "understand better what amenity level in an area was if they had one measure of park space, one of indoor recreation and one for shopping facilities than they would with only one mysterious measure combining all three" (Innes 1990, p. 224). This poses the problem of values and choices in weighted indices, which is added to the difficulty of clearly communicating them to policy makers (Martínez 2005).

\section{Mapping Dynamic Indicators and Patterns of Change}

The increasing availability of longitudinal social statistics due to the introduction of regular enumeration and census practices facilitated the emergence of studies aiming at monitoring change of socio-economic and quality of life conditions. Similarly, the proliferation of Geographic Information Systems (GIS) - commercially and open source available - facilitated the dissemination of mapping indicators practices making use of census data. Some of those studies include the case of cities in the global South (Baud et al. 2008, 2009), but seldom including dynamic indicators and patterns of change.

Of interest to this paper are those studies that emphasize the importance of eliciting patterns of change related to spatial inequality. In particular, the work of Davidson (1976) proposes a relevant approach to conceptualize and measure temporal comparisons and change in spatial inequalities.

The Davidson model (Fig. 1) has been empirically applied in several studies in regional and urban studies in the global North (Barke 1989; Broadway and Jesty 1998; Kitchen 2001; Knox 1982). The Davidson model has the advantage of being able to compare any dynamic indicator between two intercensal periods and identify convergence or divergence outcomes (including seven categories of change) by making use of a simple linear regression model (Barke 1989).

\section{Spatial Inequalities in Quality of Life}

Quality of life reflects the well-being of individuals and societies across different dimensions or domains (Sirgy et al. 2006). There is no agreement as to whether quality of life should be limited to objective or subjective measures. Some studies place emphasis on observable characteristics relying on objective indicators derived from secondary data, e.g. census data (Apparicio et al. 2008). Other studies place emphasis on the resident's perception and satisfaction with urban living conditions and their own lives, relying on surveys (Tesfazghi et al. 2010).

In Latin America, several models have been proposed to measure the quality of life. For the case of Argentina, some authors advocate for a combination of objective and subjective indicators (Celemín et al. 2015). Tonon and de la Vega (2016) have developed a model with several domains covering a rich variety of socio-demographic variables interlinked with the complex problem of inequalities. This can be illustrated by the rationale behind the dwelling domain where the authors argue that "the question of dwelling and access to a dwelling place is closely related to other social phenomena such as the social fracture derived from the process of economic restructuring" (Tonon and de la Vega 2016, p. 9). This concern is also reflected in the field of geography where several studies helped to gain a better understanding of quality of life and its spatial variation in Argentina. In the context 


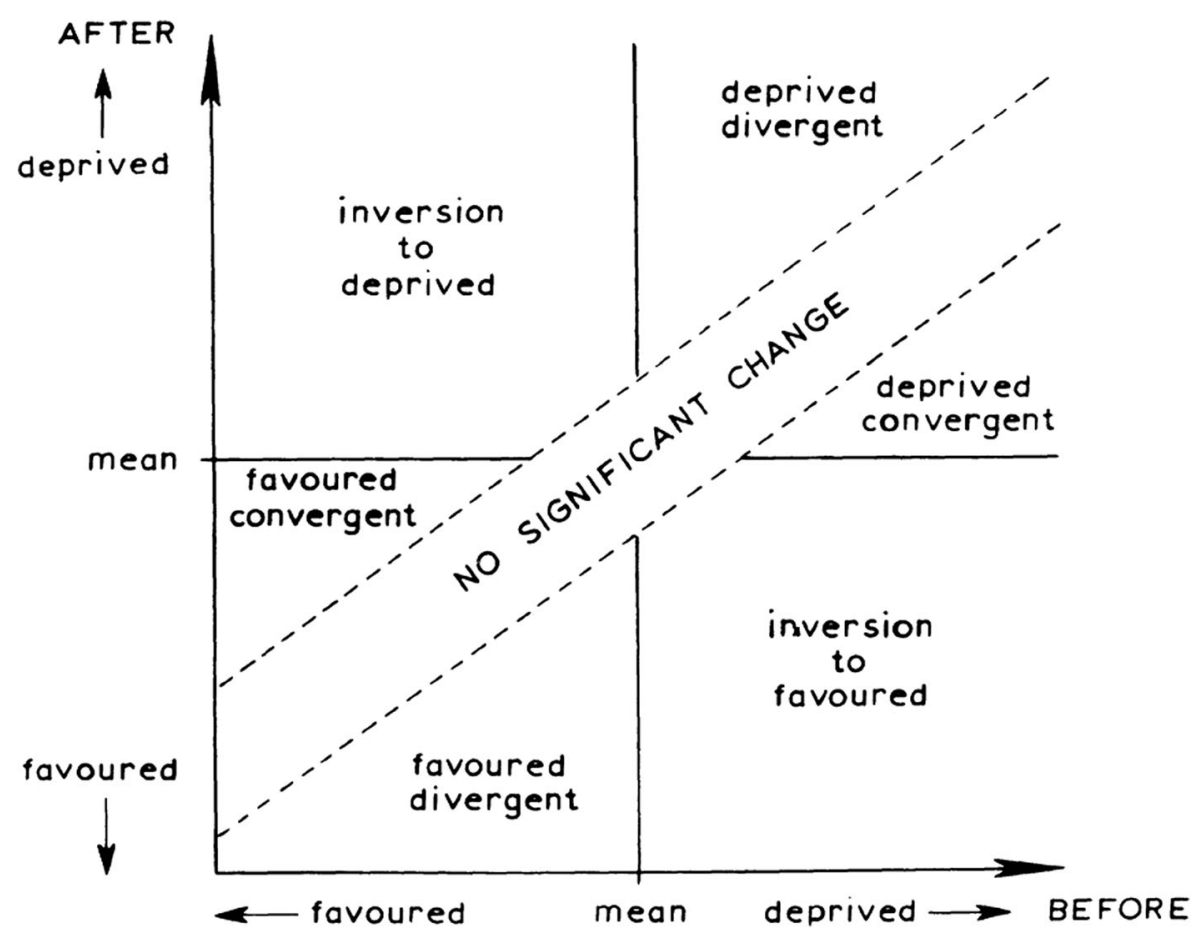

Fig. 1 Outcome regions for change in spatial inequalities. From "Social Deprivation: An Analysis of Intercensal Change" by Davidson, R. N., 1976, Transactions of the Institute of British Geographers, 1(1), 110. Copyright 1964 by Wiley. Reprinted with permission.

of this study, it is worth mentioning studies such as the analysis of quality of life satisfaction in the city of Mar del Plata (Lucero et al. 2008) and the seminal work on social differentiation in Argentina carried out by Velázquez (2001), where the variations in quality of life at regional and departmental level are also contextualized with the problem of fragmentation. In these two studies, the geographic perspective and the GIS tools proved to be relevant for the analysis and visualization of patterns of inequalities in the quality of life.

Patterns of inequalities in quality of life conditions are relevant from a social justice perspective approach (Smith 1994). The spatial dimension of inequality is highly relevant, since the scale adopted will to a large extent define the problem itself, as the degree of inequality observed will be very much a function of scale (Smith 1994).

Spatial inequalities are found and studied at different levels; similarly, "gaps" can be observed at different geographical scales. At a global level, inequalities are found between countries and at the end of the scale; at local or intra-city level, inequalities are found between neighbourhoods. This paper specifically focuses on intra-urban inequalities mapped at neighbourhood level.

This concern about spatial disparities and spatial injustice in geographical studies appeared during the 1970s, and there was an interest in influencing public policy. Since the 1990s, there has again been a growing engagement of geographers with inequalities and moral and social issues, including the theme of the ethics of professional practice 
(e.g. Couclelis 1999). This concern is particularly evident and is reflected in different reports and initiatives of international organisations that are stressing the importance of monitoring spatial inequalities within cities (e.g. European Commission 2000; European Communities 2000; The World Bank 1996; UNCHS 1995, 2001; UNDP 2000, 2001). More recently initiatives measuring the Human Developing Index at subcity level, Millennium Development Goals (MDGs) and Sustainable Development Goals (SDGs) again put an emphasis on inequalities (Lang and Lingnau 2015).

Even though there is a growing literature about inequalities and the importance of measuring them, there is not sufficient discussion about methods and tools (e.g. indicators), about how suitable they are, and about the introduction of new ones (e.g. GIS-based ones). This concern is also expressed by Kunzmann, who describes the problem as a lack of "spatially relevant indicators" (Kunzmann 1998, p. 108).

Area-based policies usually make use of socio-territorial indicators and spatial inequalities in quality of life conditions studies to target relatively disadvantaged areas. Some critics of using area-based policy strategies to reduce inequalities argue that the targeting is not based on needs, but on a demand criterion, ${ }^{2}$ that the areas are not homogeneous (ecological fallacy) and that inequality is a national problem that requires national solutions (Pantazis and Gordon 2000). Taking this into consideration, and to reduce the problems of ecological fallacy and MAUP, this study focuses on the use of small area units and low levels of aggregation, and stresses "need" more than any other distributive criterion.

The influence of the areal unit definition in the description of inequalities in quality of life conditions is highly relevant because of the scale factor. Previous research on segregation that involved comparative studies between European cities (Kruythoff 1998) shows how the areal analysis unit (e.g. municipality, district, and neighbourhood) and the average population per unit influence appreciation of the phenomenon. As can be expected, spatial differences might be smaller in larger areal units of analysis. Initiatives to gather indicators at neighbourhood level are taking place and they reveal that differences within the city are so marked that averaging social indicators at district level leads to wrong diagnoses and policy allocation mistakes (Kingsley 1999). Hence, using indicators at higher levels of aggregation can be misleading if this problem is not considered.

In this study, the scale and unit of analysis is that of the neighbourhood area which is the lowest level of administrative intervention in the case study area. The indicator used to illustrate this approach is that of overcrowding. Objective quality of life conditions such as dwelling can be measured with indicators of inadequate housing or by overcrowding (insufficient living space). ${ }^{3}$ The indicator of overcrowding is a good example to demonstrate how intra-urban indicators can clearly expose inequality. There are many reasons for choosing overcrowding. First, policy makers in Rosario value overcrowding as the most important aspect of inequalities and the majority of them

\footnotetext{
${ }^{2}$ In redistributive justice terms, demand criterion occurs where active participation in distributive decisions is "rewarded" by increased user benefit. This can be related to the lobbying power of certain groups. An example of this power is explained by Werna (2001, p. 1) in the following way: "Wealthy people often use their connections to - and influence upon - government officials to attract public investments and services to the neighbourhoods where they live, at the expense of low-income neighbourhoods. Thus, in such circumstances, the poor, through their contributions to the public system, actually subsidize the wealthy."

${ }^{3}$ Here we use the following overcrowding definition: Percentage of households with three or more persons per room. The rationale behind this indicator is that when households live in a dwelling with a number of bedrooms inadequate for the type of family, it represents a critical level of housing need. This indicator also measures the mismatch between the housing needs of the households and the dwelling size.
} 
agree that it is possible to improve the situation through the intervention of the local government (e.g. by improving housing conditions) (Martinez 2009). Secondly, overcrowding is highly and significantly correlated with other indicators of quality of life conditions such as health, education level and unemployment. Thirdly, overcrowding is one of the Millennium Development Goals indicators used to identify slum areas (UNHABITAT 2003) further carried on in the Sustainable Development Goal 11 aiming at making "cities and human settlements inclusive, safe, resilient and sustainable" by 2030 (United Nations 2017).

\section{Methods}

This section discusses the main characteristics of the study area (Rosario, Argentina) and the methodological approach.

\section{The Case of Rosario}

Rosario is the third largest city in Argentina, after Buenos Aires and Córdoba. It is located in the south of the province of Santa Fé, along the western bank of the Paraná river, and is approximately $300 \mathrm{~km}$ north-west of Buenos Aires. According to the latest census, Rosario had a population of 948,312 and it is estimated that it reached 985,626 inhabitants by 2015 with the highest density in the district "Centro" (Table 1).

The spatial boundary of this case study corresponds to the administrative boundary of the Municipality of Rosario and its six administrative districts (Fig. 2). It is part of the Rosario Department ${ }^{4}$ and accounts for $79.4 \%$ of its total population. The minimum unit of spatial representation used in this paper corresponds to the census tracts ${ }^{5}$ nested within the boundaries of the Municipality of Rosario (Fig. 2).

Throughout its history, Rosario has benefited from economic prosperity characterised by its harbour and by its industrial, commercial and financial activities. However, unequal quality of life conditions are reflected in the different levels of housing quality and access to services (i.e. infrastructure and social services). In the second half of the twentieth century, owing to urban and rural migration (caused mainly by the deterioration of regional economies), informal settlements started to grow. By 1996, (Fundación Banco Municipal 1996) 91 informal settlements were inhabited by 22,685 families $(113,382$ inhabitants, $11 \%$ of the total population of Rosario). At the same time, the number of gated communities increased during the $1990 \mathrm{~s}$, causing an increase in housing inequality, disparities and social segregation. Bragos et al. (2001) explain that, even though the first gated communities were built close to low-income residential areas, in the last years developers have been trying to "clean" the land for new investments and (low-income) families are moving out looking for cheaper land sold by the same developer. According to the same authors, this generates the formation of clusters of homogeneous groups of similar social conditions, education, age, family type, and ideal way of life (Bragos et al. 2001).

\footnotetext{
${ }^{4}$ Department is an administrative subdivision of the province of Santa Fé. Rosario is head of the department.

${ }^{5}$ Note that larger sizes of census tracts correspond to less urbanized and less populated areas.
} 
Table 1 Population, area and density by administrative districts 2015

\begin{tabular}{llll}
\hline & Population & Area $\left(\mathrm{km}^{2}\right)$ & Density $\left(\right.$ Pop $\left./ \mathrm{km}^{2}\right)$ \\
\hline Rosario (total) & 985,626 & 178.7 & 5515.8 \\
Centro (Centre) & 253,499 & 20.4 & $12,444.7$ \\
Norte (North) & 143,070 & 35.0 & 4085.4 \\
Noroeste (Northwest) & 178,157 & 44.1 & 4036.2 \\
Oeste (West) & 138,825 & 40.2 & 3452.5 \\
Sudoeste (Southwest) & 120,299 & 20.2 & 5958.3 \\
Sur (South) & 151,776 & 18.8 & 8090.4 \\
\hline
\end{tabular}

Dirección General de Estadística -DGE (2016) “Anuario de Población y Estadísticas Vitales Año 2015”. Municipality of Rosario

In 1995, the Municipality of Rosario started a decentralisation processes to create six administrative districts - and later in 2003 created 38 neighbourhood areas - aiming at reducing disparities and improving the quality of life across the different districts. In the main policy report on the decentralisation of the Municipality of Rosario, one of the most important goals mentioned is: "To decentralize so as to get a more balanced city and with more equity" (Municipalidad de Rosario 1996, p. 12). Other planning instruments incorporated in the second half of the 1990s include similar social justice and equity perspectives. According to the strategic plan, one of the roles that the city of Rosario was adopting was: "[ $\mathrm{t}]$ he generation of new mechanisms to redistribute wealth and balance social inequalities generated by the high economic concentration, improving the quality of life of its citizens" (Plan Estratégico Rosario (PER) 1998, p. 13). In the 2010s, this concern for the reduction of disparities and quality of life improvement has been maintained in the objectives of more recent planning instruments (e.g. Urban Plan Plan Urbano and Participatory Budgeting).

The municipal office responsible for housing and habitat issues in Rosario is the Public Housing Service (SPVyH: Servicio Público de la Vivienda y Habitat). The main policy of the office is to solve the problem of informal settlements ${ }^{6}$, improving not only the quality of life of their inhabitants but also regenerating the urban tissue (SPV 2003). Since 2001, its main programme has been Rosario Hábitat: a comprehensive program for improvement of informal settlements including a loan of US\$ 43 million (Steinberg 2005) from the Inter-American Development Bank to implement this programme. Notwithstanding, the challenges faced by dwellers of informal settlements have not been solved and inequalities remain. The number of people living in slum areas was estimated at 150,000 and distributed over 91 informal settlements (SPV 2003), with more recent figures adding up to 98 informal settlements, occupying 367,60 ha. (Municipalidad de Rosario 2011).

A relevant indicator for objective quality of life conditions and health dimensions in particular is infant mortality (see: Celemín et al. 2015). It has been highly associated with overcrowding (Cage and Foster 2002) and other low environmental indicators typical of slum areas (Martinez et al. 2008; UN-HABITAT 2009). A comparison of

\footnotetext{
${ }^{6}$ In this case, informal settlements refer to spontaneous urbanization with irregular occupation on private or public land (for a more detailed discussion and categorization see: (Almansi 2009)
} 


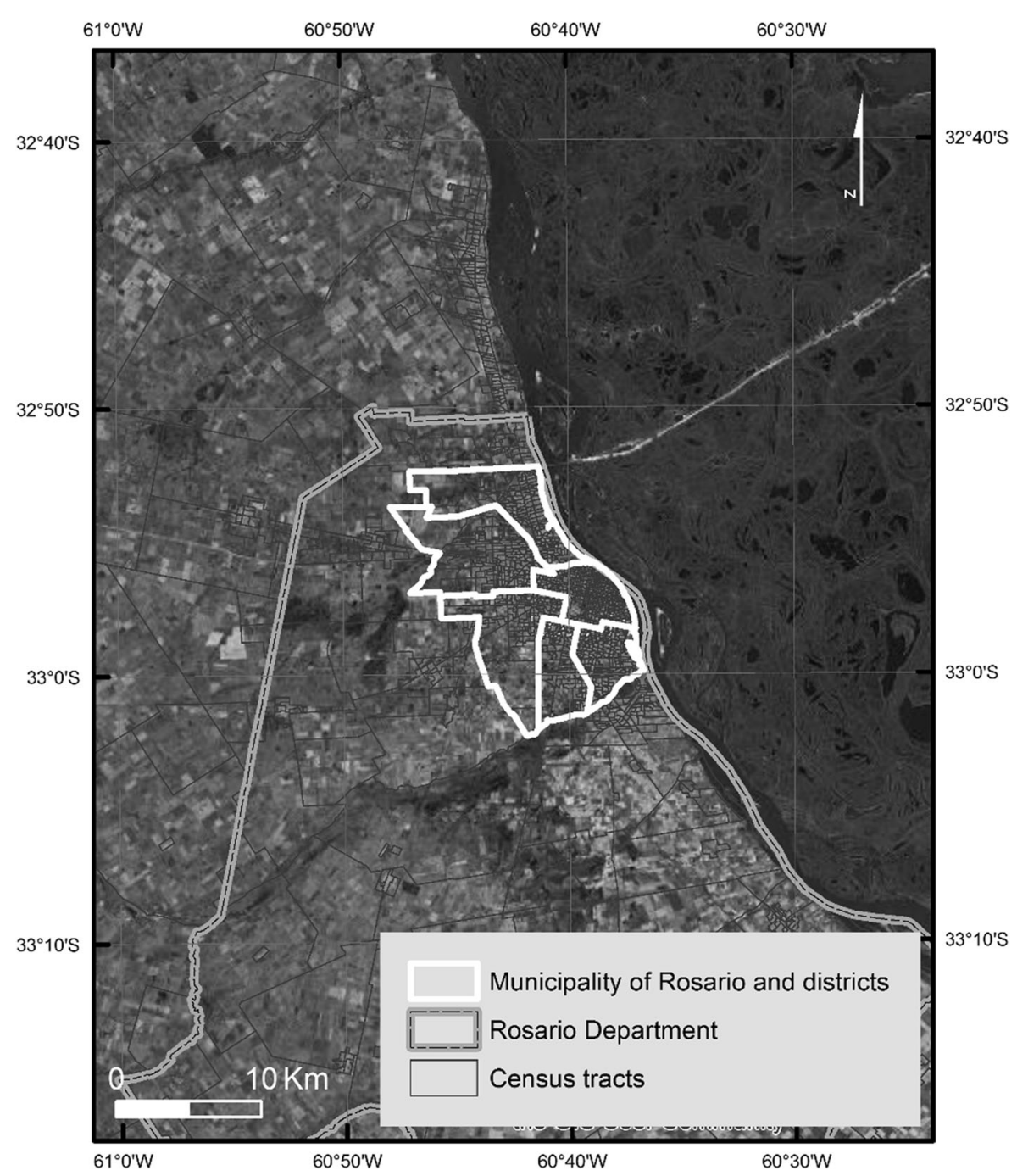

Fig. 2 Location of case study area, Municipality of Rosario. Note: data for census tracts and departmental boundaries from INDEC 2015. "Unidades Geoestadísticas. Cartografía y códigos geográficos del Sistema Estadístico Nacional. Buenos Aires: INDEC" Access date: 20/05/2017. Available on: http://www.indec.gov. ar/codgeo.asp

infant mortality in Rosario for 2001, 2010 and 2010 gives a good indication of remaining spatial disparities between the districts (Table 2).

\section{Relative Change Analysis and Mapping}

This study adapted Davidson model (Fig. 1) to emphasize the analysis of gap change between neighbourhood areas and to map the possible outcomes with a Geographic Information System (GIS). This study tested the model and the approach in the case of Rosario (Argentina). Temporal comparisons between the years 1991, 2001 and 2010 are performed to monitor the trends in improving the quality of life and reducing inequalities 
Table 2 Infant mortality in Rosario by districts 2001-2010 - 2015

\begin{tabular}{llll}
\hline & \multicolumn{2}{l}{ Infant mortality $(/ 1000)$} & \\
\cline { 2 - 4 } & 2001 & 2010 & 2015 \\
\hline Rosario (total) & 12.76 & 10.62 & 8,79 \\
Centro & 8.51 & 6.95 & 8,56 \\
Norte & 11.77 & 4.85 & 10,22 \\
Noroeste & 14.07 & 9.22 & 7,40 \\
Oeste & 17.06 & 15.00 & 11,20 \\
Sudoeste & 11.92 & 8.76 & 7,52 \\
Sur & 10.43 & 14.83 & 7,69 \\
\hline
\end{tabular}

Data for infant mortality 2015 from DGE (2016) for 2001 and 2010 from Secretaría de Salud Pública (2013)

between neighbourhood areas. It should be noticed that the focus is on relative gap change where variations in one neighbourhood are assessed in relation to other areas (city average) ${ }^{7}$. Three main hypotheses can be expected from this model:

- Areas of divergence: an increase in the inequalities;

- Areas of convergence: a decrease in the inequalities;

- Areas of maintenance of the status quo.

For each year (before and after situations), every neighbourhood area is classified against the city mean. Areas above the mean are considered better-off areas while areas below the mean are considered worse-off areas. Finally, neighbourhood areas are classified as no (significant) change when they are close to the regression line ( $\pm 0.5 \mathrm{SD})$. Table 3 presents the seven possible outcomes or regions of change.

\section{Census Data and Mapping}

The maps that visualize the spatio-temporal quality of life change and relative position of each neighbourhood were produced using census data ${ }^{8}$ obtained from INDEC (year 2001) and IPEC (year 2010) and census block group boundaries aggregated into neighbourhood areas. Within a GIS, census variables ${ }^{9}$ and boundaries were used to construct and map the

\footnotetext{
${ }^{7}$ Absolute change has been also mapped using GIS.

${ }^{8}$ The census in Argentina takes place every 10 years and is a complete count census, which means that every household in the country is visited. The population data obtained in the census correspond to the de facto population, which refers to all persons present in the household on the night of the census. The 2001 census took place on the 17th and 18th November 2001, and no sampling methods were used, using a single questionnaire (INDEC 2003). The 2010 census took place on the 27th October 2010 (INDEC 2012) and sampling methods were used to collect some variables (included in a separate extended questionnaire for those sampled households). For comparability reasons the variables of 2010 used in this paper are part of the basic questionnaire where no sampling methods were used.

${ }_{9}^{9}$ INDEC calculates overcrowding per room (hacinamiento por cuarto) by dividing the total number of persons living in the household by the total number of rooms "of household exclusive usage". INDEC defines cuarto as a "room separated by walls (from floor to roof) that can have a bed for an adult. The kitchen and the bathroom are not considered rooms, neither garages, corridors or laundry rooms. In houses with more than one household, the common rooms are not counted as rooms."
} 
Table 3 Possible groups of neighbourhood areas based on regions for change (adapted from Davidson 1976, p. 110)

\begin{tabular}{lllll}
\hline & Gap & Before & After & Relative position \\
\hline 1. No Significant Change & Stable & Worse off / Better off & Stable (close to regression line) \\
2. Inversion to Better off & Reduced & Worse off & Better off & Improvement \\
3. Better off convergent & & Better off & Better off & Decline (converges towards the city mean) \\
4. Worse off Convergent & & Worse off & Worse off & Improvement (converges towards the city mean) \\
5. Inversion to Worse off & Increased & Better off & Worse off & Decline \\
6. Worse off Divergent & & Worse off & Worse off & Decline \\
7. Better off Divergent & & Better off & Better off & Improvement \\
\hline
\end{tabular}

overcrowding indicator at block group level and neighbourhood level. Block groups correspond to the geography of the census in Argentina and neighbourhood areas are administrative units key for policy intervention. The spatial detail of the census data is determined by the boundaries of each census tract or block group (radios censales). They are established so that every polygon has a similar amount of population regardless of its geographical size and an average of 300 dwellings per census block group. Block groups are formed by blocks (manzanas), the lowest level of aggregation, but for reasons of confidentiality, data at such a level are not available. The variation in overcrowding between census years (1991, 2001, and 2010) is also calculated as the difference between the two years under comparison and analysed within the aggregated census blocks (polygon areas).

Two of the main limitations of census data are that spatial boundaries of the census are prone to changes over time and that the variables are only updated every 10 years. Variations in the spatial boundaries represent an important challenge for the analysis of spatio-temporal changes in inequalities between 1991, 2001 and 2010. The strategy followed to address the change in census boundaries was to summarise the 2001 census block groups into 1991 census block groups. Each block group of 2010 also included the identification number corresponding to the 2001 boundary where it was previously nested. This was feasible since the 2001 and 2010 census increased the number of census block groups but kept them nested in the boundaries of previous years. This empirical study offers an analysis of relative change up to 2010, which corresponds to the latest available census data. Further studies could explore, in a mixed-methods approach, the potential use of qualitative methods such as focus group discussions with policy makers and local experts' interviews in order to identify emerging trends beyond 2010 and until the upcoming census update.

It should be noted that census data are for Argentina one of the main sources of small-area data. There is high potential in the use of block-level census data, in particular to better address MAUP problems and boundary problems between censuses. The obvious advantage of using data at such a small area level is the detail and the possibility of aggregating the data later on for any other administrative or neighbourhood areas rather than the block groups. Unfortunately, for reasons of confidentiality, data at block level or "manzanas" are not available. In this respect, concern is expressed in National Census Bureau reports (INDEC 2001), although the absence of this level of detail has been justified in the previous censuses by disclosure restrictions and regulations (Law 17,622). Either a new interpretation or a new law will be required to allow the release of data at block level. 


\section{Areal Unit of Analysis and Policy Intervention Areas}

Bearing in mind that indicators of quality of life should be related to policy actions, it is important to see how inequality is also depicted at a level of aggregation coincident with the area of policy intervention. In many cities, this is the case with the municipality districts. Policy makers might prefer to act at district level, where neighbourhood participation activities also take place. In the case of Rosario, every district was subdivided by the municipality into six or seven areas barriales or neighbourhood areas. Moreover, this is the minimum scale of policy application by policy makers. For this reason, the overcrowding indicator used in this study is calculated at block group level (census tract) but also aggregated and summarised within a GIS into neighbourhood areas.

\section{Results / Discussion}

The following sections analyse in detail the change in overcrowding between 1991 and 2001 and between 2001 and 2010 for all the neighbourhood areas in Rosario. As expected by the hypothesis of change three main outcomes were obtained:

- Areas of divergence: an increase in the inequalities (relative decline);

- Areas of convergence: a decrease in the inequalities (relative improvement);

- Areas of maintenance of the status quo (relative stability).

\section{Change 1991-2010}

Figure 3 shows the distribution of all neighbourhood areas classified against the city mean overcrowding of 1991 and 2001. Eight neighbourhood areas show a tendency towards equality (worse-off convergence) and one neighbourhood area (Sudoeste 3 -SO3) is in the area where it can be considered that there is an inversion to better-off or favoured. Only the district Centro ( $\mathrm{Cl}-\mathrm{C} 7)$ has all its neighbourhood areas located in the better-off area.

Two neighbourhood areas of the district Oeste (O6 and O5) clearly appear in the worse-off divergent zone (showing an increase in overcrowding levels).

Figure 4 shows the census block groups where in absolute terms overcrowding is reduced and where it has got worse. By comparing the distribution of overcrowding between 1991 and 2001, it can be observed that the best-off areas remain much the same. There is a drop in overcrowding in most of the periphery, measured both in absolute values (total overcrowded households) and as a percentage of overcrowded households. However, in some block groups in the periphery more than 250 households became more overcrowded.

To comprehend this situation better, it is necessary to analyse the population growth between the two years. Figure 5 shows that between 1991 and 2001 the city centre lost population whereas the periphery gained population. The population in Rosario grew from 907,175 in 1991 to 922,444 in 2001, which represents an overall growth of only $2 \%$, compared with the $14 \%$ growth registered in the previous two censuses. In the same period, the natural growth amounted to 61,361 persons. The difference with the overall growth of 15,269 persons results in a net migration balance of 46,000 persons. 


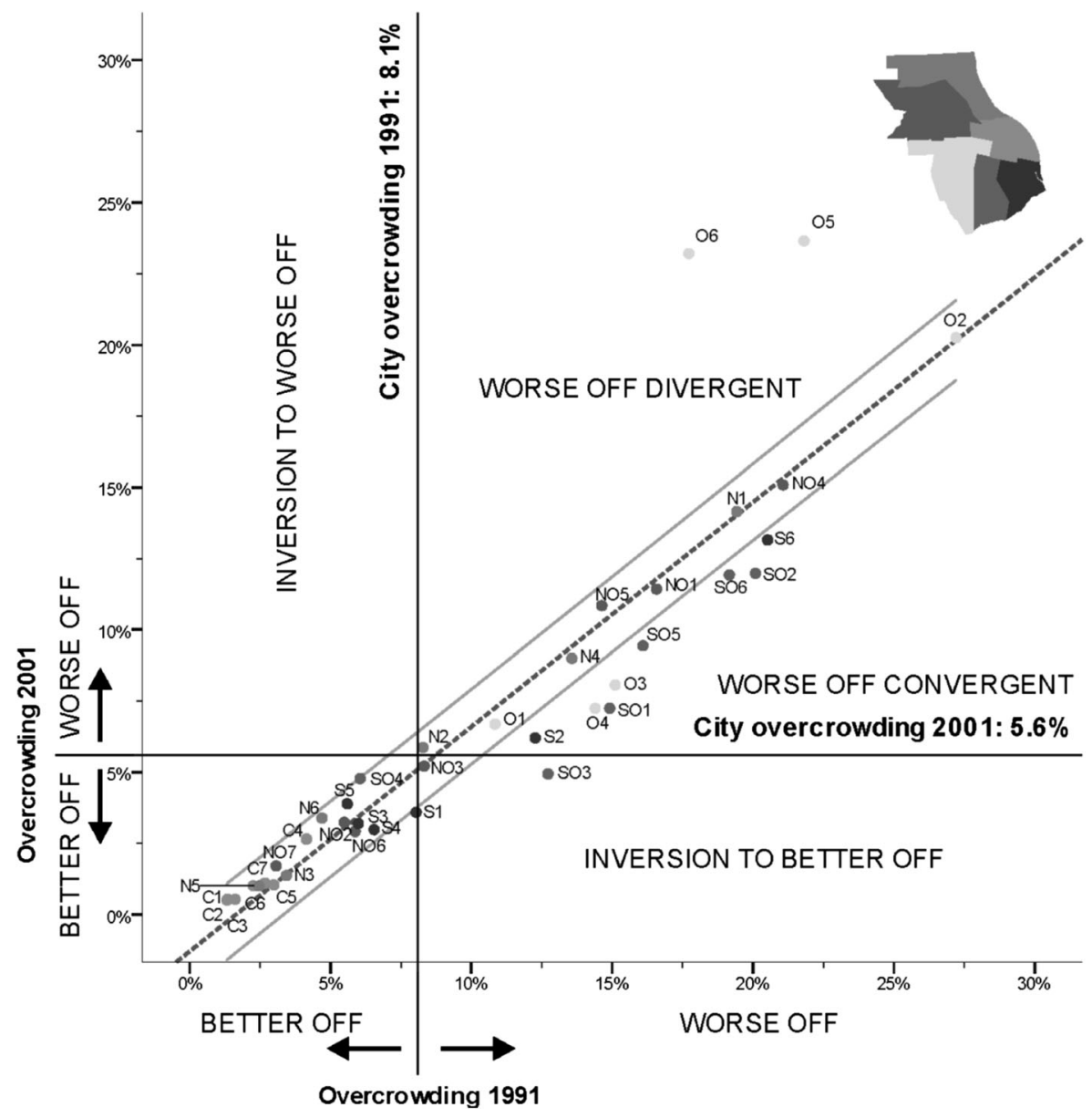

Fig. 3 Change in overcrowding 1991-2001 in Rosario's neighbourhood areas

The low population growth between the two years could be related to the deindustrialisation that affected the metropolitan area (which started in the 1970s). Consequently, the city of Rosario attracted fewer migrants. At the same time, other cities in the metropolitan area registered a higher population growth (e.g. Funes and Roldán $^{10}$ ). The development of gated communities in those areas might explain some displacement from the city centre and its population loss ${ }^{11}$. On the other hand, the growth in the periphery might be related to the fact that in the worst-off areas families tend to be more numerous (which is confirmed by a higher percentage of children than in other areas - See Table in Annex A) and/or that migrating families from other provinces settle in worst-off areas.

\footnotetext{
${ }^{10}$ Located on the West axis of the metropolitan area of Rosario. Funes grew from 8952 in 1991 to 14,665 in 2001 and Roldán from 9382 to 11,470 (source: INDEC).

${ }^{11}$ This phenomenon is not unique to Rosario as other Latin American cities in the past 20 years have been characterized by an urban development process where the periphery traditionally occupied by lower income groups (either in informal settlements or social housing) is now shared by middle and upper income class population living in gated communities (Roitman and Phelps 2011).
} 


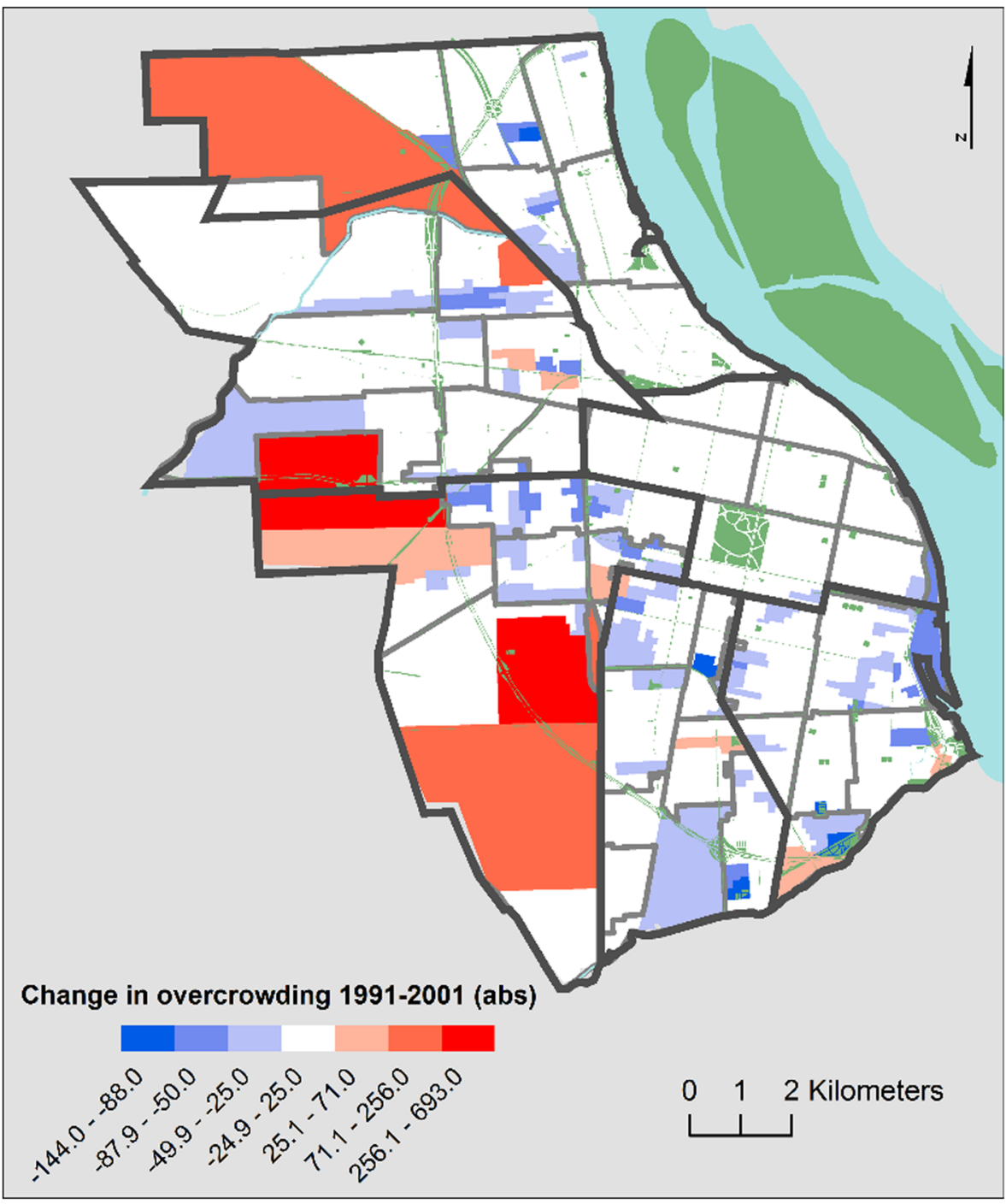

Fig. 4 Change in overcrowding 1991-2001 (absolute number of overcrowded households) at block group level

On balance, the best-off areas lost population and the worst-off areas gained population. This might explain why there is an increase in overcrowding in some areas of the periphery.

According to the president of the municipal parliament of Rosario, the district Oeste is the area of the city with the greatest population growth in recent times and many deprivations are concentrated in this district. This is because new slums have emerged next to new housing areas. He added that the demands emerging from the participatory budget sessions from the district Oeste were evidence of the city's "internal debt" with the peripheral neighbourhoods, with more investment being required (La Capital 2004).

Another phenomenon that might explain the increase in overcrowding in a few block groups of the city centre is the increase in the number of pensions (boarding 


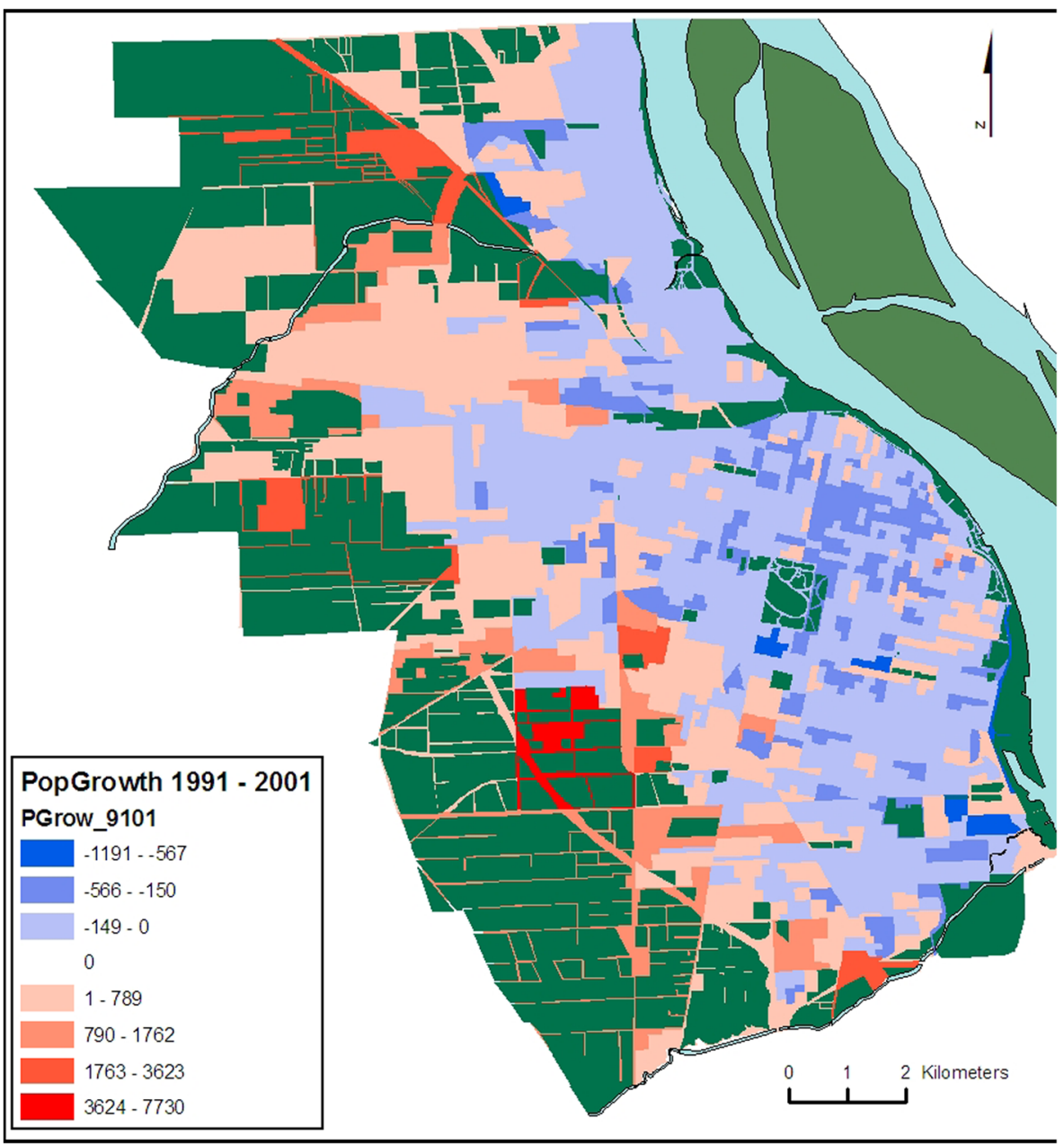

Fig. 5 Population growth 1991-2001 (in green, predominantly green and unbuilt areas)

houses). These are non-tourist pensions, where dwellers pay a monthly rent for rooms that are usually located on the upper floors of shops or old houses.

If the change in inequalities in the quality of life is analysed taking into account the physical environment, there is an increase in inadequate housing in the city centre (most probably new poor) and an accentuation of deprivations in the periphery. On the other hand, the decrease in overcrowding in some areas might be explained by the increase in public housing and the clearance of slum areas. Five years before the 2001 census, 15,000 people moved from slum areas to live in a public housing area (Dezorzi 2001).

\section{Change 2001-2010 Compared to 1991-2001}

By analysing areas of change between 2001 and 2010 it can be observed that six neighbourhood areas show a tendency towards equality (worse-off convergence) and 


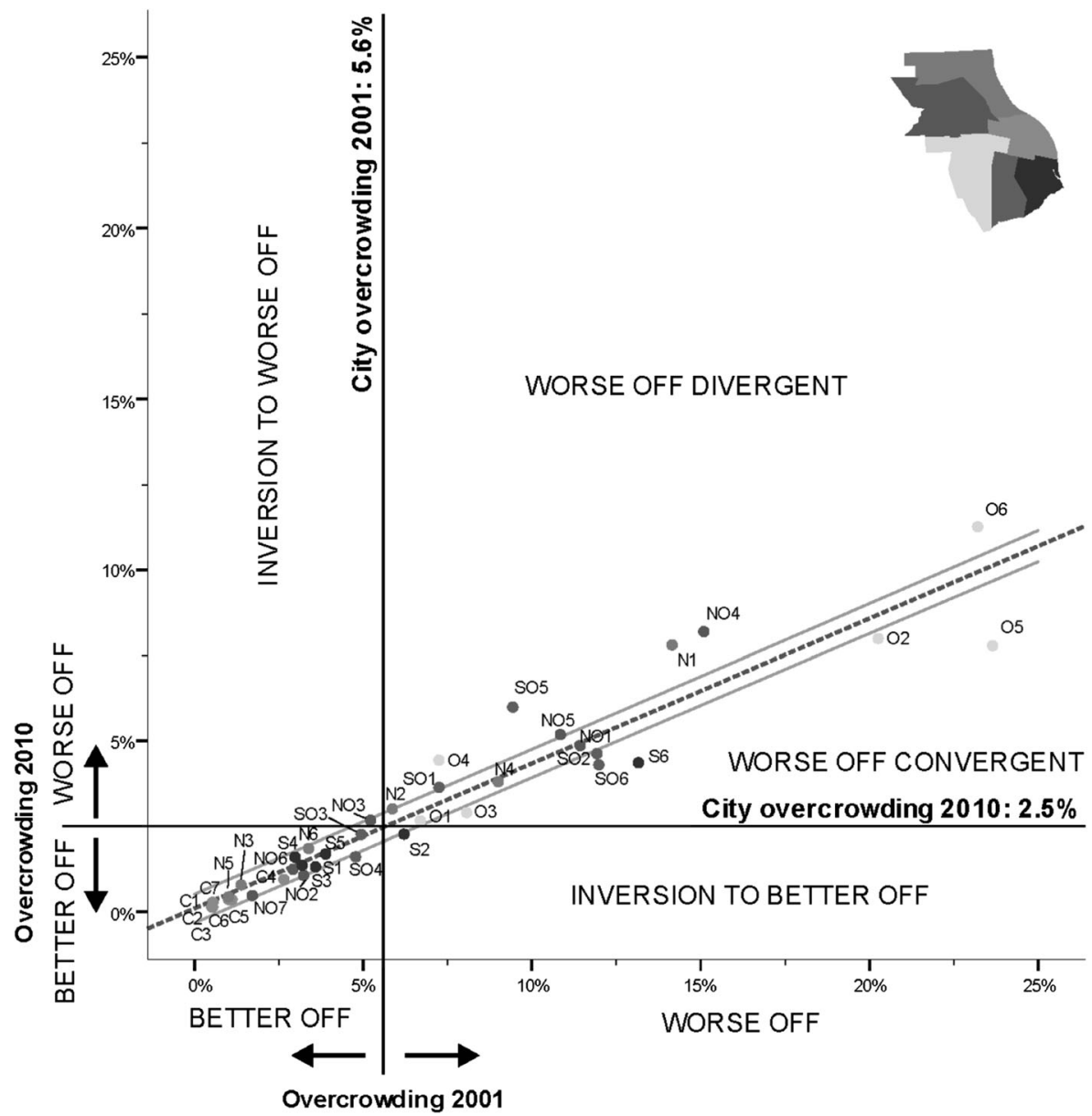

Fig. 6 Change in overcrowding 2001-2010 in Rosario's neighbourhood areas

that they are all located in the districts Sur, Oeste and Sudoeste (S, O, and SO in Fig. 6). In contrast to the areas of change of 1991-2001, the latest census information of 2010 shows that no neighbourhood area moved to inversion to better-off or favoured. Similarly to the 1991-2001 change, only the district Centro has all its neighbourhood areas located in the better-off area.

Supporting the hypothesis of divergence and relative decline, six neighbourhood areas appear in the worse-off divergent zone (showing a relative increase in overcrowding gap).

The analysis of change between 2001 and 2010 could be very useful to policy makers in allocating resources and observing trends. In particular, Fig. 7 shows a reduction of overcrowding in the periphery between 2001 and 2010 that might be explained by the implementation of housing policies targeting slum areas such as the comprehensive program for improvement of informal settlements Rosario Hábitat ${ }^{12}$. However, by

\footnotetext{
12 This programme included physical aspects such as the improvement of existing housing and public infrastructure, urban upgrading, relocations and land titling; as well as social aspects such improving social networks and participation (Almansi 2009).
} 


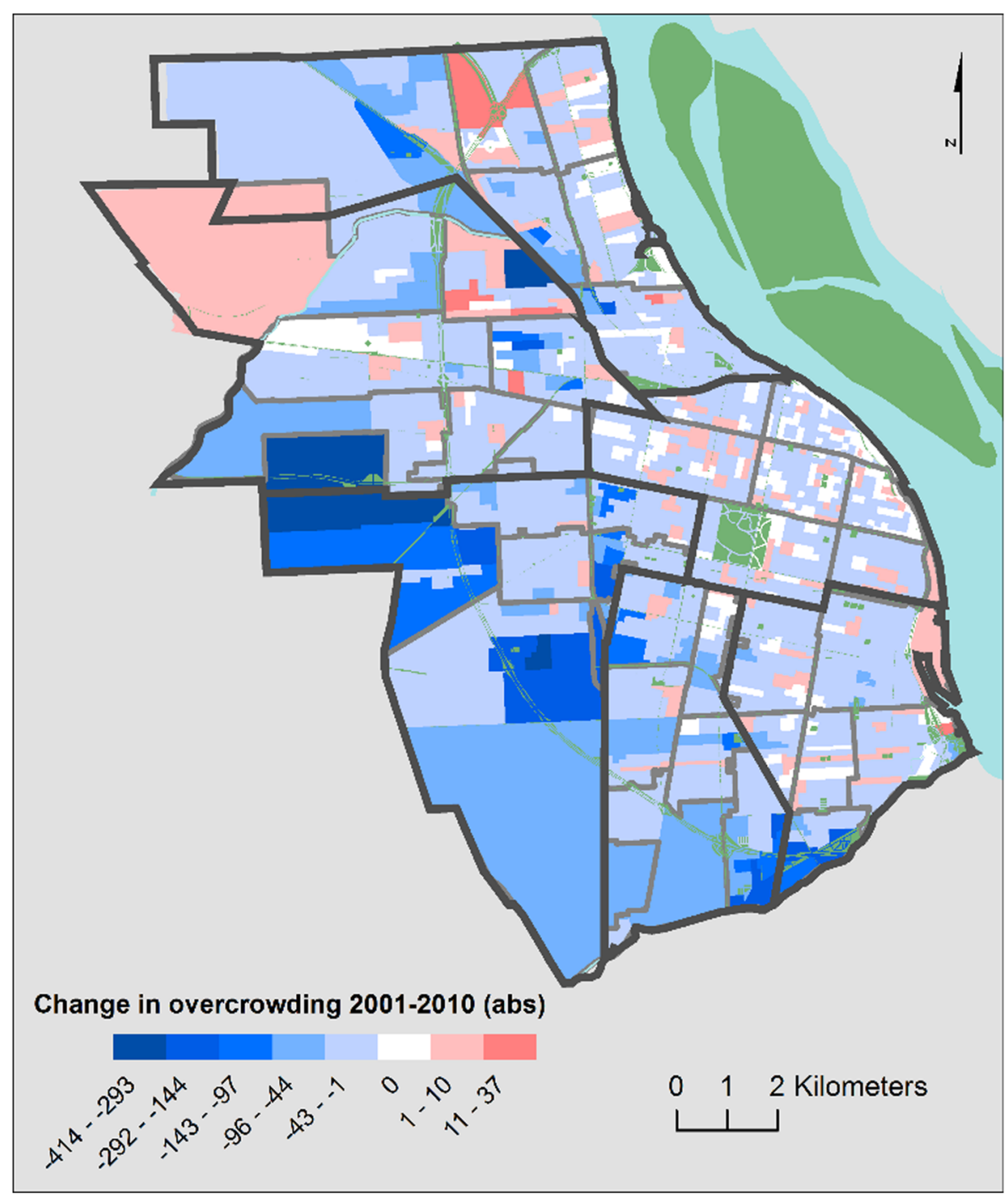

Fig. 7 Change in overcrowding 2001-2010 (absolute number of overcrowded households) at block group level

analysing areas of change (Fig. 8) and in relative terms the patterns of inequality remain the same with clear better-off areas mostly concentrated in the district Centro.

\section{Conclusions}

This paper compared variations in time and space across districts and neighbourhood areas of the city of Rosario (Argentina). Census data of 1991, 2001 and 2010 have been used to map and trace the relative position of neighbourhood areas in relation to objective quality of life conditions and overcrowding in particular. In this methodology, 


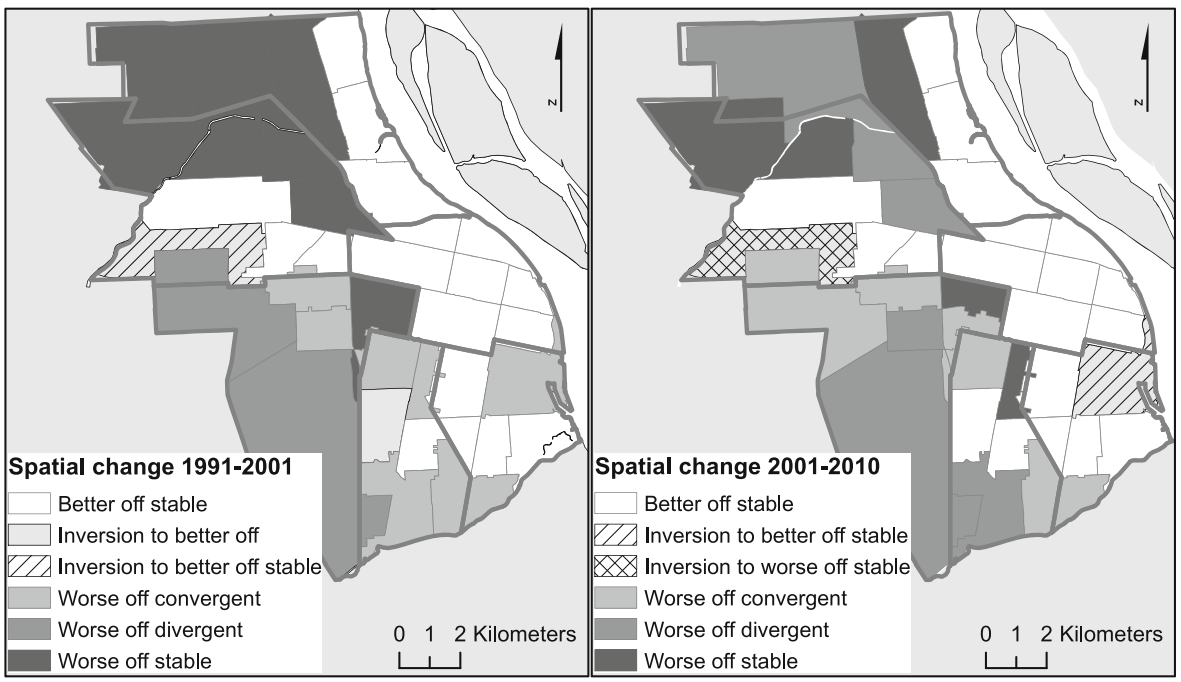

Fig. 8 Areas of change at neighbourhood area level. a- 1991-2001, b-2001-210

temporal comparisons between the years 1991 and 2001 and 2001 and 2010 have been performed to monitor the trends in improving the quality of life and reducing inequalities between neighbourhood areas.

The main conclusion is that areas of maintenance and convergence showing relative improvement towards equalization are found across the three census years analysed. Nevertheless, some areas - mostly in the periphery - are getting relatively worse in comparison with the rest of the city; these are areas probably requiring the attention of policy makers. Some of the factors explaining these trends are related to the deep socio-economic crisis of 2001 and the relative improvement and recovery reflected in the 2010 census.

One of the structural and driving forces of overcrowding in Latin American cities is that migrant groups have serious difficulties in finding adequate housing. This urbanization pattern is reflected in the increasing informality in the access to land and housing and social exclusion (Castagna et al. 2014; Corbetta and Rosas 2017). In some cases, despite the fact that public authorities recognize the overcrowding problem as a priority, they do not seem to consider it when it comes to implement the housing programs (Rosenstein 2008) or they are faced with obstacles such as land scarcity or lack of adequate regulations when it comes to regularizing existing informal settlements (Almansi 2009). These driving forces and insufficient policy responses hinder the possibility of some groups to have access to adequate housing and to improve their quality of life. The capacity and potential of dynamic indicators of quality of life rely on how the selection of indicators contemplates specific policy requirements, concerns and context. In the case of Rosario, this paper illustrated a methodological approach by mapping relative change in overcrowding which had been signalled as a key indicator of spatial inequality by local policy makers (Martinez 2009) and within a context of decentralization and social justice perspective.

Furthermore, scale issues in the monitoring of gaps and boundaries related to specific administrative units relevant to local policymaking practices - i.e. neighbourhood areas - should be considered. In this respect, the use of maps and 
cartographic visualization that can easily be communicated to policy makers (and thus likely to be applied by them) is of importance.

The use of GIS was clearly an advantage at the time of constructing indicators, combining census data, visualising the change in gaps between two intercensal periods and mapping areas of change. Some challenges remain in terms of boundary changes over time and not completely nested boundaries of census tracts in neighbourhood areas and districts. Equally to observations made by Phillips (2003) on the disadvantages of GIS in mapping community indicators, it should be noticed that not all of the dimensions of quality of life and inequality can be spatially represented or translated into a geographic context.

This case study shows the existing capacity of dynamic indicators and the potential they have - mediated by planning and policy practices - to influence on quality of life conditions and community well-being. The prescriptive application of this methodology and mapping of areas of change could help policy makers and planners in the identification and targeting of worse-off areas or areas of relative decline.

Acknowledgements This work was supported by the Ministry of Education of the Republic of Korea and the National Research Foundation of Korea (NRF-2016S1A3A2924563).

\section{Annex}

Table 4 Neighbourhood areas and \% of population 0-14 (ranked on \% overcrowding above city level - 2001)

\begin{tabular}{|c|c|c|c|c|c|c|}
\hline & $\begin{array}{l}\text { Neighbourhood } \\
\text { Area }\end{array}$ & $\%$ Overcrowding & $\begin{array}{l}\% \text { Children Pop } \\
0-14 \text { years }\end{array}$ & Min Overc. & Max Overc. & Standard Deviation \\
\hline 1 & Oeste 5 & 23.6 & 34.4 & 4.4 & 49.1 & 15 \\
\hline 2 & Oeste 6 & 23.2 & 35.9 & 1.9 & 48.6 & 14 \\
\hline 3 & Oeste 2 & 20.3 & 33.5 & 5.0 & 33.2 & 11 \\
\hline 4 & Noroeste 4 & 15.1 & 30.7 & 3.7 & 33.3 & 8 \\
\hline 5 & Norte 1 & 14.1 & 30.6 & 4.4 & 31.7 & 10 \\
\hline 6 & Sur 6 & 13.2 & 29.4 & 4.6 & 24.3 & 9 \\
\hline 7 & Sudoeste 6 & 12.0 & 28.9 & 2.7 & 22.5 & 8 \\
\hline 8 & Sudoeste 2 & 11.9 & 26.9 & 1.9 & 29.9 & 7 \\
\hline 9 & Noroeste 1 & 11.4 & 29.6 & 0.0 & 22.9 & 8 \\
\hline 10 & Noroeste 5 & 10.8 & 26.2 & 0.5 & 36.4 & 8 \\
\hline 11 & Sudoeste 5 & 9.4 & 28.2 & 2.2 & 18.8 & 8 \\
\hline 12 & Norte 4 & 9.0 & 26.5 & 0.8 & 24.1 & 6 \\
\hline 13 & Oeste 3 & 8.1 & 25.0 & 2.5 & 15.9 & 4 \\
\hline 14 & Sudoeste 1 & 7.2 & 25.2 & 0.0 & 19.9 & 7 \\
\hline 15 & Oeste 4 & 7.2 & 24.2 & 2.7 & 14.7 & 4 \\
\hline 16 & Oeste 1 & 6.7 & 22.1 & 0.4 & 24.3 & 7 \\
\hline 17 & Sur 2 & 6.2 & 22.5 & 0.0 & 23.4 & 6 \\
\hline \multirow[t]{2}{*}{18} & Norte 2 & 5.9 & 22.4 & 0.0 & 26.8 & 8 \\
\hline & Rosario & 5.6 & 21.7 & & & \\
\hline
\end{tabular}

${ }^{\text {a }}$ Standard deviation calculated among the block groups of the corresponding neighbourhood area 
Open Access This article is distributed under the terms of the Creative Commons Attribution 4.0 International License (http://creativecommons.org/licenses/by/4.0/), which permits unrestricted use, distribution, and reproduction in any medium, provided you give appropriate credit to the original author(s) and the source, provide a link to the Creative Commons license, and indicate if changes were made.

\section{References}

Almansi, F. (2009). Regularizing land tenure within upgrading programmes in Argentina; the cases of Promeba and Rosario Hábitat. Environment and Urbanization, 21(2), 389-413.

Apparicio, P., Séguin, A.-M., \& Naud, D. (2008). The quality of the urban environment around public housing buildings in Montréal: An objective approach based on GIS and multivariate statistical analysis. Social Indicators Research, 86(3), 355-380.

Barke, M. (1989). Provincial disparities in levels of living: The case of Spain, 1970-1981. GeoJournal, 18(4), 407-416.

Baud, I., Sridharan, N., \& Pfeffer, K. (2008). Mapping urban poverty for local governance in an Indian megacity: The case of Delhi. Urban Studies, 45(7), 1385-1412.

Baud, I. S. A., Pfeffer, K., Sridharan, N., \& Nainan, N. (2009). Matching deprivation mapping to urban governance in three Indian mega-cities. Habitat International, 33(4), 365-377.

Booth, C. (1902). Life and Labour of the People in London. London: Macmillan.

Bragos, O., Mateos, A., \& Pontoni, S. (2001). Social and spatial segregation in Rosario west side expansion. Paper presented at the 37th International ISOCARP Congress, Utrecht, The Netherlands.

Broadway, M. J., \& Jesty, G. (1998). Are Canadian inner cities becoming more dissimilar? An analysis of urban deprivation indicators. Urban Studies, 35(9), 1423-1438.

Cage, R. A., \& Foster, J. (2002). Overcrowding and infant mortality: A tale of two cities. Scottish Journal of Political Economy, 49(2), 129-149.

Castagna, A., Raposo, I., \& Woelflin, M. (2014). Crecimiento económico y desarrollo urbano. La problemática de los asentamientos irregulares en Rosario. Salvador: Paper presented at the XIII Seminario Internacional de la Red Iberoamericana de Investigadores sobre Globalización y Territorio (RII).

Celemín, J. P., Mikkelsen, C., \& Velázquez, G. (2015). La calidad de vida desde una perspectiva geográfica: integración de indicadores objetivos y subjetivos. Revista Universitaria de Geografia, 24(1), 63-84.

Chakravorty, S. (1996). A measurement of spatial disparity: The case of income inequality. Urban Studies, 33(9), 1671-1686.

Corbetta, S., \& Rosas, C. (2017). Urban habitat and indigenous migrants. The case of the Qom indigenous group in the city of Rosario, Argentina. Población \& Sociedad, 24(1), 5-33.

Couclelis, H. (1999). Spatial information technologies and societal problems. In M. Craglia \& H. Onsrud (Eds.), Geographic information research: Trans-Atlantic perspectives (pp. 15-24). London: Taylor \& Francis.

Davidson, R. N. (1976). Social deprivation: An analysis of Intercensal change. Transactions of the Institute of British Geographers, 1(1), 108-117.

Dezorzi, S. (2001, April 15). De la villa a la urbanización: un cambio de vida que llega con contradicciones. La Capital.

Dirección General de Estadística-DGE. (2016). Anuario de Población y Estadísticas Vitales Año 2015. Rosario: Municipality of Rosario.

European Commission. (2000). Towards a local sustainability profile: European common indicators (p. 12). Luxemburg: Directorate-General for the Environment - European Commission.

European Communities. (2000). The Urban Audit. Towards the Benchmarking of Quality of Life in 58 European Cities. Luxemburg: Office for Official Publications of the European Communities.

Fundación Banco Municipal. (1996). Asentamientos irregulares en Rosario 1996. Rosario: Fundación Banco Municipal.

Harvey, D. (1973). Social justice and the city. London: Edward Arnold.

Harvey, D. (1997) Justice, nature and the geography of difference (R ed.): Malden, Mass., etc.] : Blackwell.

Harvey, D. (2000). Spaces of hope. Edinburgh: Edinburgh University Press.

Hay, A. M. (1995). Concepts of equity, fairness and justice in geographical studies. Transactions of the Institute of British Geographers, 20, 500-508.

INDEC. (2001). Alcances del Secreto Estadístico en el Censo Revista Informativa del Censo 2001. Aquí Se Cuenta (p. 24). Buenos Aires: INDEC.

INDEC. (2003). Evolución de la población y variación intercensal absoluta y relativa. Años 1869-2001 (Vol. 2003). Buenos Aires: INDEC. 
INDEC. (2012). Censo Nacional de Población, Hogares y Viviendas 2010. Censo del Bicentenario. Resultados definitivos. Serie B N 2 Tomo 1. Buenos Aires: INDEC.

INDEC. (2015). Unidades Geoestadísticas. Cartografía y códigos geográficos del Sistema Estadístico Nacional. Buenos Aires: INDEC.

Innes, J. E. (1990). Knowledge and public policy: The search for meaningful indicators (2nd ed.). New Brunswick: Transaction Publishers.

Kingsley, T. G. (1999). Building and operating neighbourhood indicator systems: A Guidebook. Washington D.C.: The Urban Institute.

Kitchen, P. (2001). An approach for measuring urban deprivation change: The example of East Montr,al and the Montr,al Urban Community, 1986-96. Environment and Planning A, 33(11), 1901-1921.

Knox, P. L. (1982). Regional inequality and the welfare state: Convergence and divergence in levels of living in the United Kingdom, 1951-1971. Social Indicators Research, 10(3), 319-335.

Knox, P. L., \& Pinch, S. (2000). Urban social geography : An introduction (4th ed.). Harlow: Prentice Hall.

Kruythoff, H. (1998). Segregation diagnostics, antisegregation remedies, six European case-studies reviewed. In H. Priemus, R. van Kempen, \& S. Musterd (Eds.), Towards undivided cities in Western Europe. New challenges for urban policy. Part 7 Comparative analysis. (Vol. 7). Delft: Delft University Press.

Kunzmann, K. R. (1998). Planning for spatial equity in Europe. International Planning Studies, 3(1), 101-120.

La Capital. (2004). El Concejo Municipal trata hoy los reclamos del Distrito Oeste. La Capital. Retrieved from http://archivo.lacapital.com.ar/2004/07/08/ciudad/noticia_114458.shtml

Lang, V. F., \& Lingnau, H. (2015). Defining and measuring poverty and inequality post-2015. Journal of International Development, 27(3), 399-414.

Lucero, P., Rivière, I., Ares, S., Aveni, S., Celemín, J. P., Mikkelsen, C., Ondartz, A., Sabuda, F. (2008) Perspectiva geográfica de la satisfacción vital: salud, seguridad y vivienda en la ciudad de Mar del Plata. In G. Tonon (Ed.), Desigualdades Sociales y Oportunidades Ciudadanas (pp. 123-152). Buenos Aires: Espacio Editorial.

Martínez, J. A. (2005). Monitoring intra-urban inequalities with GIS-based indicators. With a case study in Rosario, Argentina. Enschede: Utrecht University - ITC.

Martinez, J. (2009). The use of GIS and indicators to monitor intra-urban inequalities. A case study in Rosario, Argentina. Habitat International, 33(4), 387-396. https://doi.org/10.1016/j.habitatint.2008.12.003

Martinez, J., Mboup, G., Sliuzas, R., \& Stein, A. (2008). Trends in urban and slum indicators across developing world cities, 1990-2003. Habitat International, 32(1), 86-108.

Municipalidad de Rosario. (1996). Documento Base Para la Descentralización de la Municipalidad de Rosario [base document for the decentralization of the municipality of Rosario]. Rosario: Programa de Descentralización y Modernización. Secretaría General de la Municipalidad de Rosario.

Municipalidad de Rosario. (2011). Plan Urbano Rosario 2007-2017. Municipalidad de Rosario: Rosario.

Pacione, M. (2001). Urban geography, a global perspective. London: Routledge.

Pantazis, C., \& Gordon, D. (2000). Tackling inequalities : Where are we now and what can be done? Bristol: Policy Press.

Phillips, R. (2003) Community indicators. Chicago (122 S. Michigan Ave., Suite 1600, Chicago 60603): American Planning Association.

Plan Estratégico Rosario (PER). (1998). Plan Estratégico Rosario, Diagnóstico y Formulación. Rosario: PER y Agencia Española de Cooperación Internacional.

Rogerson, P. (2010). Statistical methods for geography: A student's guide (3rd ed.). Los Angeles: Sage.

Roitman, S., \& Phelps, N. (2011). Do gates negate the City? Gated communities' contribution to the urbanisation of suburbia in Pilar, Argentina. Urban Studies, 48(16), 3487-3509.

Rosenstein, C. (2008). El programa rosario hábitat y la integración como factor de mejora en la calidad de vida. El caso del asentamlento "La Lagunita". Estudios del hábitat. Universidad Nacional de La Plata. Facultad de arquitectura y urbanismo, 10(February), 59-73.

Secretaría de Salud Pública. (2013). La mortalidad infantil en la última década en la ciudad de Rosario. Rosario: Municipality of Rosario.

Shevky, E., \& Bell, W. (1955). Social Area Analysis. Standford: Standford University Press.

Sirgy, M. J., Michalos, A. C., Ferriss, A. L., Easterlin, R. A., Patrick, D., \& Pavot, W. (2006). The quality-oflife (QOL) research movement: Past, present, and future. Social Indicators Research, 76(3), 343-466.

Smith, D. M. (1973). The geography of social well-being in the United States : An introduction to territorial social indicators. New York: McGraw-Hill.

Smith, D. M. (1994). Geography and social justice. Oxford: Blackwell.

Soja, E. W. (2010). Seeking spatial justice. Minneapolis: University of Minnesota Press.

SPV. (2003). Programa Rosario Hábitat. Descripción (Vol. 2003). Rosario: SPV. Municipalidad de Rosario. 
Steinberg, F. (2005). Strategic urban planning in Latin America: Experiences of building and managing the future. Habitat International, 29(1), 69-93.

Tesfazghi, E., Martínez, J. A., \& Verplanke, J. (2010). Variability of quality of life at small scales: Addis Ababa, Kirkos Sub-City. Social Indicators Research, 98(1), 73-88.

The World Bank. (1996). Urban poverty research sourcebook. Module II: Indicators of urban poverty. In C. Moser, M. Gatehouse, \& H. Garcia (Eds.). Washington: The World Bank.

Tonon, G., \& de la Vega, L. R. (2016). Measuring quality of life and inequalities in South America. In G. Tonon (Ed.), Indicators of quality of life in Latin America (pp. 3-17). Cham: Springer International Publishing.

UNCHS. (1995). Indicators Programme, Volume 1, 2 and 3 (Vol. 1). Nairobi: UNCHS.

UNCHS. (2001). Cities in a Globalizing World. Global Report on Human Settlements 2001 (p. 344). London: Earthscan.

UNDP. (2000). Chapter 5: Using indicators for human rights accountability. In UNDP (Ed.), Human Development Report 2000 (pp. 89-111). Oxford: Oxford University Press.

UNDP. (2001). Human Development Report 2001. Oxford: Oxford University Press.

UN-HABITAT. (2003). Guide to monitoring target 11: Improving the lives of 100 million slum dwellers. In Progress towards the millennium development goals. UN-HABITAT: Nairobi.

UN-HABITAT. (2009). Urban indicators guidelines: Better information, better cities. Monitoring the habitat agenda and the millennium development goals-slums target. UN-HABITAT: Nairobi.

United Nations. (2017). Report of the inter-agency and expert group on sustainable development goal indicators (E/CN.3/2017/2), Annex III: United Nations.

Velázquez, G. Á. (2001). Geografia, calidad de vida y fragmentación en la Argentina de los noventa: análisis regional y departamental utilizando SIG's. Tandil: Universidad Nacional del Centro de la Provincia de Buenos Aires, CIG-Centro de Investigaciones Geográficas.

Werna, E. (2001). Combating urban inequalities: Challenges for managing cities in the developing world. Northampton: Edward Elgar Pub.

Zorbaugh, H. (1961). The Natural Areas of the City. In G. Theodorson (Ed.), Studies in Human Ecology (pp. 45-49). New York: Harper and Row. 